\title{
Mechanism of Selective Translation of Vaccinia Virus mRNAs: Differential Role of Poly(A) and Initiation Factors in the Translation of Viral and Cellular mRNAs
}

\author{
R. BABLANIAN, ${ }^{1 *}$ S. K. GOSWAMI, ${ }^{1}$ M. ESTEBAN, ${ }^{1}$ A. K. BANERJEE, ${ }^{2}$ AND W. C. MERRICK ${ }^{3}$ \\ Department of Microbiology and Immunology, SUNY Health Science Center at Brooklyn, Brooklyn, New York 11203 ${ }^{1}$; \\ Department of Molecular Biology, Research Institute, The Cleveland Clinic Foundation, Cleveland, Ohio 441952; and \\ Department of Biochemistry, School of Medicine, Case Western Reserve University, Cleveland, Ohio 44106 ${ }^{3}$
}

Received 19 February 1991/Accepted 10 May 1991

\begin{abstract}
We have recently demonstrated that the poly $(A)$ moieties of short RNAs obtained from both in vitro transcription and from vaccinia virus (VV)-infected cells exhibit dissimilar effects on the in vitro translation of cellular and VV mRNAs (R. Bablanian, G. Coppola, P. Masters, and A. K. Banerjee, Virology 148:375-380, 1986; M. J. Su and R. Bablanian, Virology 179:679-693, 1990). In the present study, we have investigated the roles of poly(A), $\mathbf{m}^{7} \mathbf{G T P}$, and initiation factors in the mechanism of selective translation of VV mRNAs. The effects of unfractionated poly $(A)$ [termed poly $(A)_{u n}$, with various chain lengths up to 3,000 nucleotides] and a 150- to 300-nucleotide fraction of synthetic poly $(A)$ [termed poly $(A)_{150-300}$ ] on the translation of $\mathrm{HeLa}$ cell mRNAs and early and late VV mRNAs were studied. Both the poly $(\mathbf{A})_{\text {un }}$ and the poly $(\mathbf{A})_{150-300}$ completely inhibited the translation of HeLa cell mRNAs obtained from total cytoplasmic RNA in the nuclease-treated reticulocyte lysates. Viral mRNAs from total cytoplasmic RNA also were slightly inhibited (15 to $38 \%$ ) by the $\operatorname{poly}(A)_{u n}$, whereas the poly $(A)_{150-300}$ had no significant effect on their translation. The translation of oligo(dT)cellulose-selected HeLa mRNAs was as sensitive to inhibition by poly(A) $)_{150-300}$ as the mRNAs found in total cytoplasmic RNA. However, the translations of oligo(dT)-cellulose-selected viral mRNAs become more sensitive to the inhibitory effect of poly $(A)_{150-300}$ than the translations of viral $m R N A s$ found in the total cytoplasmic RNA. Both HeLa and VV mRNAs became more resistant to the poly(A)-mediated inhibition when these mRNAs were deadenylated, but the relative resistance to inhibition by poly $(A)_{150-300}$ of deadenylated $\mathrm{VV}$ mRNAs was much greater than that of HeLa cell mRNAs. The translation of VV mRNAs was significantly less inhibited than the translation of HeLa mRNAs when the cap analog, $\mathrm{m}^{7} \mathrm{GTP}$, was added to the cell-free system. The inhibition of HeLa cell mRNA translation by both poly $(A)_{u n}$ and poly $(A)_{150-300}$ was completely restored when poly(A)-binding protein (PAB) was added to the cell-free translational system. The addition of eukaryotic initiation factor $4 \mathrm{~A}$ (eIF-4A) did not restore translation when poly $(A)_{\text {un }}$ was used to inhibit translation; however, inhibition by poly $(A)_{150-300}$ was significantly reversed by this initiation factor. The reversal of poly (A)-mediated inhibition of HeLa cell mRNA translation was additive when PAB was used together with eIF-4A. Early VV mRNA translation was only slightly inhibited by poly $(A)_{\text {un }}(15 \%)$, and this inhibition was completely reversed by either PAB or eIF-4A. Late viral mRNAs were also moderately inhibited by poly(A) un $(38 \%)$, but this inhibition was reversed only by PAB and not by eIF-4A. Our findings demonstrate that cellular and viral mRNAs respond differently to poly $(A)$, to initiation factors, and to a cap analog, suggesting that structural differences between these mRNAs might account for selective translation of VV mRNAs over host mRNAs.
\end{abstract}

The ribohomopolymer poly(A), found at the $3^{\prime}$ terminus of most eukaryotic mRNAs, has been implicated in a number of cellular functions, but the precise role of poly(A) in translation has not yet been determined $(11,53)$. It was first observed by Lodish and Nathan (34) that several polynucleotides, including poly(A), inhibited translation of mRNAs in reticulocyte lysates at the level of initiation. In a later study, however, it was suggested that poly(A), as opposed to other homopolymers, was a specific inhibitor of protein synthesis (21). These authors demonstrated that free poly(A) preferentially affected the rate of translation of poly $(\mathrm{A})^{+}$rather than $\operatorname{poly}(\mathrm{A})^{-}$mRNAs, leading to the suggestion that poly $(\mathrm{A})^{+}$mRNAs required a component found in the lysate which was being sequestered by free poly(A). A candidate for this component was speculated to be the poly(A)-binding protein (PAB) (21). These results were substantiated by the observation that the translation of poly $(\mathrm{A})^{+}$globin mRNA

\footnotetext{
* Corresponding author.
}

was sensitive but poly(A)- tobacco mosaic virus was resistant to exogenously added free $\operatorname{poly}(\mathrm{A})$ in the reticulocyte lysate system (14). Lemay and Millward (33), employing reovirus mRNAs, which are known to be naturally poly(A) ${ }^{-}$ (50), also demonstrated that the overall translation of these mRNAs was resistant to free poly(A) added to an L-cell lysate system. More recently it was demonstrated that inhibition of translation by poly(A) could be reversed by the addition of purified PAB (14). It was proposed that PAB bound to the $3^{\prime}$ terminus of mRNAs may facilitate translation through an interaction with the $60 \mathrm{~S}$ ribosomal subunit (44). Additional studies have suggested that PAB bound at the $3^{\prime}$ ends of mRNAs may facilitate the binding of an initiation factor or ribosomal subunit at the $5^{\prime}$ ends (36).

Vaccinia virus (VV) mRNAs, whether transcribed in vitro or in vivo, receive poly(A) posttranscriptionally at their $3^{\prime}$ termini, like most eukaryotic mRNAs $(12,24,25,35,37,49)$. Interestingly, it has been shown recently that $\mathrm{VV}$ late mRNAs predominantly contain poly $(A)$ of variable lengths at their $5^{\prime}$ ends as well $(1,10,47)$. The length of the $3^{\prime}$ 
poly(A)s of VV mRNAs transcribed either in vitro or in vivo are similar in size, and the majority of the chains are over 100 residues (48). The average length of the $3^{\prime}$ poly(A)s of eukaryotic mRNAs found in the cytoplasm of cells, however, is only 60 residues (11).

Work from our laboratory implicating poly(A) in the inhibition of host cell protein synthesis came from studies on VV cytopathology $(2,5-7,13,46)$. We demonstrated that small, nontranslating polyadenylated RNAs synthesized in vitro by VV selectively inhibited HeLa cell mRNAs over VV mRNAs (4). This selective inhibitory property of the small poly(A)-containing RNAs was abrogated only when the RNA was deadenylated, thus implicating poly(A) in this inhibition (3). Furthermore, we showed that synthetic poly(A) inhibited the translation of HeLa cell mRNAs more effectively than it inhibited the translation of VV mRNAs (3). However, when the synthetic poly(A), which contains both large- and small-size poly(A) classes, was fractionated, it was shown that VV mRNA translation from core-synthesized mRNAs was not significantly inhibited by the smallersize class poly(A)s, while the large-size class had an inhibitory effect on translation (8). More recently, we demonstrated that nontranslating polyadenylated sequences (POLADS) similar to those found in in vitro transcription from $\mathrm{VV}$ cores were also found in VV-infected cells. The average length of poly(A)s found at the $3^{\prime}$ ends of POLADS was over 100 residues (51), similar to the size of the $3^{\prime}$ poly(A)s of $\mathrm{VV}$ mRNAs (37). These POLADS, like their in vitro counterparts, were also shown to be selective inhibitors, because they inhibited the translation of HeLa cell mRNAs but only minimally affected the translation of VV mRNAs in the nuclease-treated reticulocyte lysates (51). The active inhibitory moiety of both the in vitro- and the in vivo-obtained POLADS was shown to be the $3^{\prime}$ poly(A) of POLADS (3, $51)$. Because of this possible in vivo role of poly $(A)$, we undertook a detailed study of the mechanism of inhibition of translation by poly(A). In this article, we compared the extents of inhibition of translation of HeLa, early VV, and late VV mRNAs caused by the heterogeneous, unfractionated poly(A) [poly $(\mathrm{A})_{\mathrm{un}}$ ] and a 150- to 300-nucleotide fraction of $\operatorname{poly}(\mathrm{A})\left[\operatorname{poly}(\mathrm{A})_{150-300}\right]$ to evaluate the role of the length of poly(A) residues in selective inhibition of polypeptide synthesis. In addition, translation of HeLa and early and late VV mRNAs in the presence or absence of exogenously added cap analog ( $\left.\mathrm{m}^{7} \mathrm{GTP}\right)$ was determined. We also studied the effects of initiation factors and $P A B$ on this inhibition of translation by poly $(\mathrm{A})_{\mathrm{un}}$ and $\operatorname{poly}(\mathrm{A})_{150-300}$. These studies suggest that selective translation of viral over host mRNAs may be related to structural differences between these $\mathrm{mR}$ NAs.

\section{MATERIALS AND METHODS}

Cells and viruses. HeLa cells were grown in suspension in Eagle's Spinner medium and supplemented with $5 \%$ newborn bovine serum. The cells were infected with plaquepurified WR strain of VV and purified according to the method of Joklik (23). The particle concentration of the purified virus was determined by spectrophotometry as previously described (7).

Chemicals. Poly (A) was purchased from Sigma Chemical Co. The specific stock we obtained was composed of various chain lengths, with the greatest concentration of these chains being in the range of 300 to 3,000 nucleotides long. Purified PAB was a generous gift of Alan B. Sachs of the Whitehead
Institute, Cambridge, Mass. Initiation factors were purified as previously described $(17,18)$.

Cell-free protein synthesizing system. Reticulocyte lysates were prepared according to the method of Schreier and Staehelin (45). The endogenous translation was essentially eliminated by treatment with micrococcal nuclease (39). Twenty-five microliters of the reaction mixture was programmed with various cellular or viral mRNAs as previously described (13).

Preparation of HeLa cell or VV-infected HeLa cell RNAs. HeLa Spinner cells or virus-infected (20 PFU per cell) HeLa Spinner cells $\left(10^{9}\right)$ were treated with $300 \mu \mathrm{g}$ of cycloheximide per $\mathrm{ml}$, and $4 \mathrm{~h}$ later, the cells were sedimented and total cytoplasmic RNA was extracted according to the method of Krystosek et al. (30). These RNAs from HeLa cells or infected HeLa cells were used for translation in the in vitro cell-free system either as total RNAs or after selection of poly(A) ${ }^{+}$RNAs by oligo(dT) chromatography.

Separation of the 100- to 200- and the 150- to 300-nucleotide poly(A) by polyacrylamide gels. Synthetic poly(A) was fractionated on a thin $(0.4 \mathrm{~mm}) 5 \%$ polyacrylamide $-42 \%$ urea gel. The 100- to 200- and the 150- to 300-nucleotide sizes were determined by comparison with the size of DNA of pUC19 cut with HpaII and terminally labeled with $\left[\alpha-{ }^{32} \mathrm{P}\right]$ dCTP by using the Klenow enzyme. These fractions of poly(A) were eluted from the gel with $0.5 \mathrm{M}$ ammonium acetate, $10 \mathrm{mM}$ EDTA, and $0.1 \%$ sodium dodecyl sulfate (SDS) at $37^{\circ} \mathrm{C}$ for $16 \mathrm{~h}$. The eluted poly(A) fractions were precipitated in ethanol at $-20^{\circ} \mathrm{C}$, dried, and dissolved in $\mathrm{H}_{2} \mathrm{O}$. The concentration of poly(A) was determined by measuring the optical density.

Deadenylation of mRNAs. The poly(A) chain at the $3^{\prime}$ ends of HeLa and early VV mRNAs was removed by ribonuclease $H$ treatment in the presence of oligo(dT) as described previously (51).

SDS-polyacrylamide gel electrophoresis (PAGE). $\left[{ }^{35}\right.$ S $] \mathrm{me}$ thionine-labeled products of in vitro translation were resolved on a 5 to $15 \%$ polyacrylamide gel according to the method of Laemmli (31) and were autoradiographed according to the method of Fairbanks et al. (16).

Quantification of polypeptide synthesis from autoradiograms. The autoradiograms obtained from polyacrylamide gels were subjected to laser densitometry with the LKB ultrascan XL apparatus. The total area of each lane was plotted on bar graphs.

\section{RESULTS}

Inhibitory effects of poly $(A)_{u n}$ and poly $(A)_{150-300}$ on the translation of HeLa cell mRNAs and early and late VV mRNAs. Our previous work had demonstrated that translation of VV core-synthesized mRNAs was much more resistant to the inhibitory effect of poly $(A)$ un than HeLa mRNA translation in the cell-free system (3). We therefore tested the effect of both poly $(A)_{\text {un }}$ and poly $(A)_{150-300}$, which approximates the size of poly $(A)$ chains expected in infected cells (37), on translation of mRNAs extracted from HeLa cells and from VV-infected cells in the nuclease-treated reticulocyte lysates. The results, shown in Fig. 1, indicate that both the $\operatorname{poly}(\mathrm{A})_{\text {un }}$ (lane 3$)$ and the poly $(\mathrm{A})_{150-300}$ (lane 4) completely inhibit HeLa cell mRNA translation. The translations of both the early (lanes 5 to 7) and late (lanes 8 to 10) VV mRNAs are inhibited by only 25 to $30 \%$ with the poly $(\mathrm{A})_{\mathrm{un}}$; however, poly $(\mathrm{A})_{150-300}$ (lanes 7 and 10) does not appear to cause any significant inhibition. These results demonstrate that $\mathrm{HeLa}$ cell mRNAs are equally sensitive to 


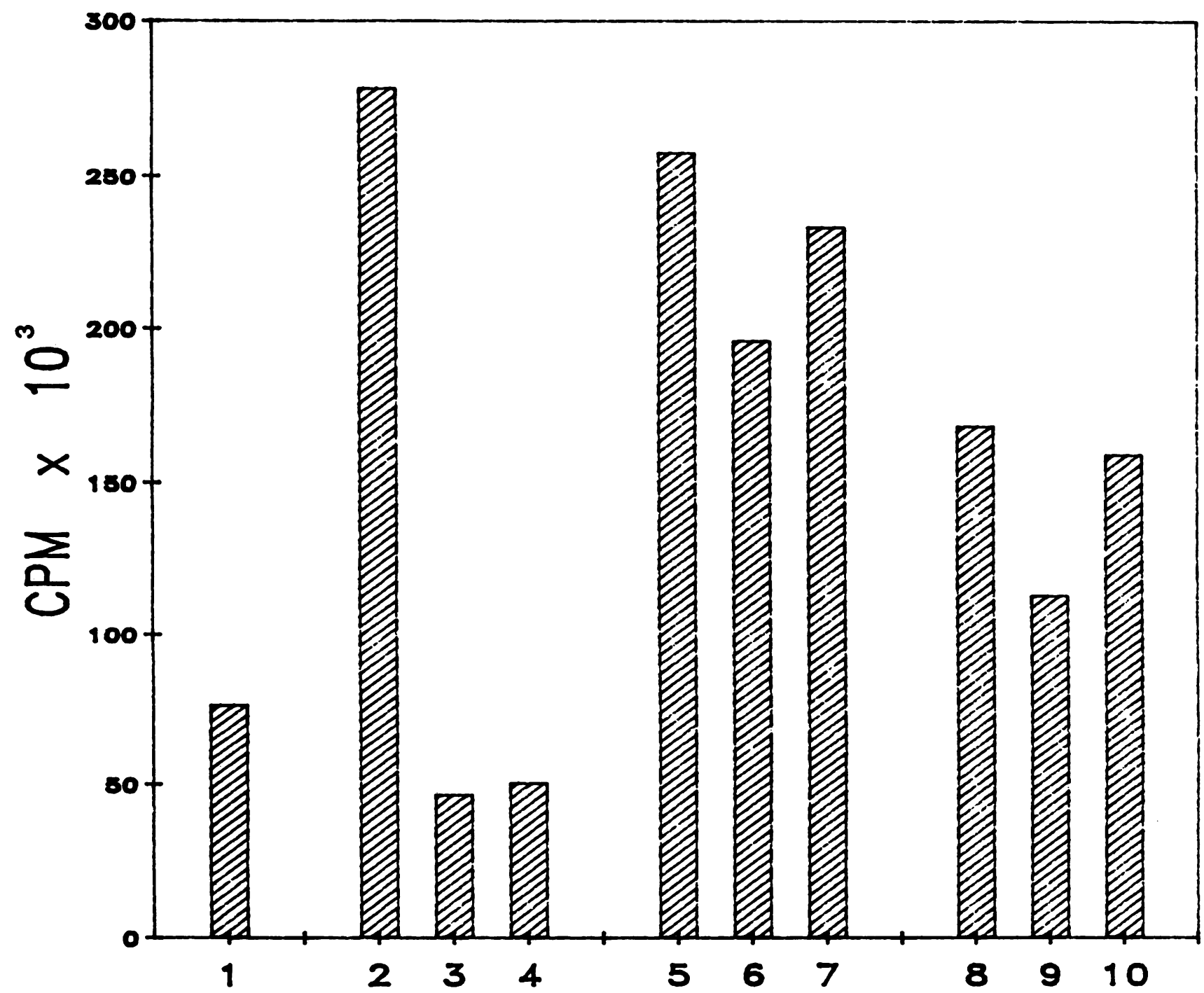

FIG. 1. Effects of poly(A) $)_{\mathrm{un}}$ and poly(A) ${ }_{150-300}$ on the translation of HeLa cell early and late VV mRNAs. HeLa cell and VV early and late mRNAs $(5 \mu \mathrm{g}$ per $25 \mu \mathrm{l})$ were translated in the nuclease-treated reticulocyte lysates in the absence or presence of poly(A) $(1 \mu \mathrm{g})$ or poly $(\mathrm{A})_{150-300}(1 \mu \mathrm{g})$. Twenty microliters of the reaction mixtures labeled with $\left[{ }^{35} \mathrm{~S}\right]$ methionine for $1 \mathrm{~h}$ at $32^{\circ} \mathrm{C}$ was acid precipitated and assayed for radioactivity in a scintillation counter. Columns are as follows: 1, no added RNA; 2 , HeLa mRNA; 3, HeLa mRNA plus poly $(A)_{u n} ; 4$, HeLa mRNA plus poly $(A)_{150-300} ; 5$, early VV mRNA; 6 , early VV mRNA plus poly $(A)_{u n} ; 7$, early VV mRNA plus poly(A) $150-300$; 8, late VV mRNA; 9, late VV mRNA plus poly $(A)_{u n}$; and 10, late VV mRNA plus poly $(A)_{150-300}$. CPM, counts per minute.

the inhibitory effect of both the unfractionated poly(A) and the smaller fraction used, whereas VV mRNAs are sensitive only to $\operatorname{poly}(\mathrm{A})_{\mathrm{un}}$.

To further characterize the poly(A)-mediated inhibition, we tested the effect of the poly(A) $)_{100-200}$ on the translation of HeLa and early VV mRNAs obtained either from total cytoplasmic RNA or after oligo(dT)-cellulose chromatography. The results of the inhibition of translation at various concentrations of $\operatorname{poly}(\mathrm{A})$ are shown by a representative experiment in Fig. 2A and B. It can be seen in Fig. 2A that the translation of the early VV mRNAs found in the total cytoplasmic RNA is highly resistant to poly $(\mathrm{A})$ over a range of concentrations used, whereas the translation of HeLa mRNAs obtained from the total cytoplasmic RNA is highly sensitive, even at the lowest concentration of poly(A). The translation of HeLa cell mRNAs obtained by oligo(dT)cellulose chromatography is as sensitive to the inhibitory effect of various concentrations of $\operatorname{poly}(\mathrm{A})$ as that found in the total cytoplasmic RNA (compare Fig. 2B and A). However, unlike the translation of VV mRNAs from the total cytoplasmic RNA, which was highly resistant to poly(A) (Fig. 2A), the translation of the VV mRNAs obtained from oligo(dT)-cellulose chromatography was somewhat inhibited, although still significantly less than the translation of HeLa mRNAs. These results clearly demonstrate that VV mRNAs from the total cytoplasmic RNA are much more resistant to the inhibitory effect of poly(A) than the oligo (dT)-cellulose-selected VV mRNAs, indicating that selection of mRNAs by means of their poly(A) tails is excluding a poly (A)-resistant moiety. 
A

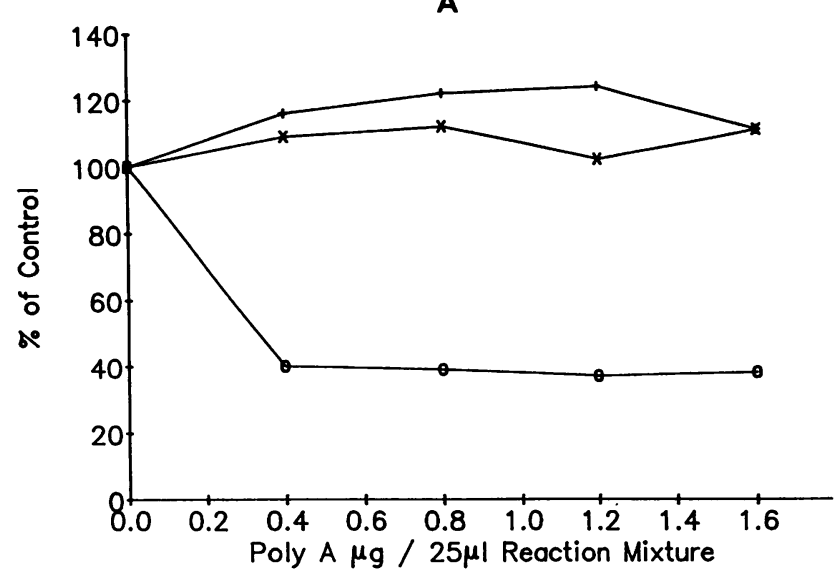

B

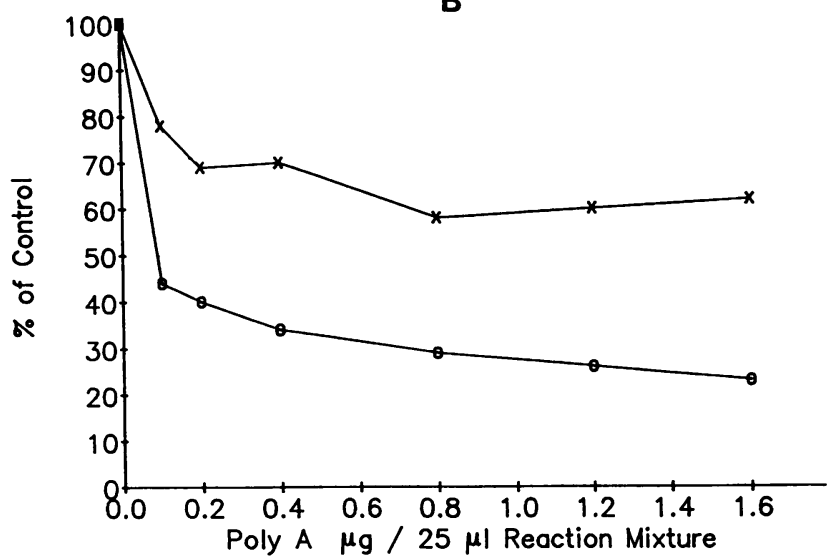

FIG. 2. Translation of HeLa and VV mRNAs obtained from total cytoplasmic RNA or after oligo(dT)-cellulose chromatography. (A) HeLa $(15 \mu \mathrm{g})$, early VV $(5 \mu \mathrm{g})$, and late VV $(7.5 \mu \mathrm{g})$ total RNAs obtained from uninfected or infected cells were added to the nuclease-treated reticulocyte lysates in the presence of various concentrations of poly $(A)_{100-200}$. Twenty microliters of the reaction mixtures were subjected to 5 to $15 \%$ PAGE and exposed to an X-ray film. The extent of translation was determined by laser densitometry of the autoradiograms and plotted as percent of control. $\mathrm{O}, \mathrm{HeLa}$ total RNA; X, early VV total RNA; +, late VV total RNA. (B) HeLa $(0.6 \mu \mathrm{g})$ and early VV $(0.2 \mu \mathrm{g})$ mRNAs, obtained by oligo(dT)cellulose chromatography, were added to the nuclease-treated reticulocyte lysates in the presence of various concentrations of poly(A) $)_{100-200}$. Twenty microliters of the reaction mixtures were subjected to 5 to $15 \%$ PAGE and exposed to X-ray film. The extent of translation was determined by laser densitometry of the autoradiogram and plotted as percent of control. $\bigcirc$, HeLa mRNA; X, early VV mRNA.

The translation of deadenylated HeLa and early VV mRNAs in reticulocyte lysates is more resistant to the inhibition by poly(A). In order to further study the difference between HeLa and VV mRNA sensitivities to poly(A)-mediated inhibition of translation, we compared the translation of deadenylated HeLa and VV mRNAs in reticulocyte lysates in the presence of various concentrations of poly(A). It has been previously shown that $m$ RNAs devoid of poly(A) tails are more resistant to the effect of exogenously added poly(A) than those possessing poly(A) tails (21). The results shown in Fig. 3A and B demonstrate that, indeed, both HeLa and VV mRNAs which have been deadenylated become much more resistant to the inhibitory effect of poly(A) at concentrations of 0.4 and $0.8 \mu \mathrm{g}$ than those possessing poly(A) tails. When higher concentrations of poly(A) $(1.6$ and $3.2 \mu \mathrm{g})$ are used, however, the translation of deadenylated HeLa mRNAs is markedly reduced, whereas that of deadenylated VV mRNAs is essentially unaffected. These results demonstrate that VV mRNAs, whether or not they possess the $3^{\prime}$ poly(A), are intrinsically more resistant to the inhibitory effect of poly(A), again pointing to a translational preference for VV mRNAs.

Translations of early and late $\mathrm{VV}$ mRNAs are more resistant to $\mathbf{m}^{7}$ GTP than that of HeLa mRNAs. It was demonstrated that VV mRNAs are capable of initiating translation more efficiently than HeLa mRNAs in the presence of poly(A), suggesting selectivity under these conditions of translation. It was, therefore, of interest to determine whether VV mRNAs also possessed a selective edge at their $5^{\prime}$ ends in translation. To this end, we tested the effect of the cap analog on the translation of HeLa and early and late VV mRNAs. The results shown in Fig. $4 \mathrm{~A}$ and $\mathrm{B}$ and Table 1 indicate that the translation of both early and late VV mRNAs is about two times more resistant to increasing concentrations of $\mathrm{m}^{7} \mathrm{GTP}$ than that of HeLa mRNAs and that the extents of inhibition of 200 or $600 \mu \mathrm{M}$ are almost equivalent. This may indicate that VV mRNAs need less eukaryotic initiation factor $4 \mathrm{~F}$ (eIF-4F) to initiate than is required for HeLa cell mRNA initiation. This result also suggests that a cap-independent mechanism may account for a portion of the VV mRNA translation.

To determine the effect of $\mathrm{m}^{7} \mathrm{GTP}$ on the translation of a mixed population of mRNAs, HeLa cell mRNAs were mixed with a fraction of early VV mRNAs which were devoid of POLADS. Since the active moiety of POLADS was shown to be poly(A), and HeLa mRNAs are sensitive to poly(A), it was essential to separate the POLADS from the mRNAs by fractionation before mixing (51). The translation of these mixed mRNAs in the absence or presence of $\mathrm{m}^{7} \mathrm{GTP}$ is shown in Fig. 5A and B and in Table 2. It can be seen that both HeLa and VV mRNAs are translated in the mixture (Fig. 5A, lane 8) in the absence of $m^{7}$ GTP. The extents of inhibition of translation of each individual polypeptide in the presence of 400 and $600 \mu \mathrm{M}$ cap analog are given in Table 2 . The mean of the inhibition of various HeLa and VV polypeptides synthesized in the presence of $\mathrm{m}^{7} \mathrm{GTP}$ is plotted in Fig. 5B. It can be seen that the extent of inhibition of polypeptide synthesis by $\mathrm{m}^{7} \mathrm{GTP}$ is two times higher with HeLa than with VV when these polypeptides are synthesized separately and about five times higher in the mixture (Fig. 5A, lanes 9 and 10, Fig. 5B, and Table 2). These results, obtained by mixing HeLa and VV mRNAs, confirm our previous observations that in the presence of $m^{7} \mathrm{GTP}, \mathrm{VV}$ mRNAs still are capable of translating much more efficiently than HeLa cell mRNAs. Moreover, during competition, the effect of $m^{7}$ GTP seems to be accentuated, i.e., the inhibition of HeLa mRNA translation in the presence of the cap analog only is $29 \%$, but when the viral and cellular mRNAs are mixed, HeLa mRNA translation is reduced to $11 \%$ in the presence of $\mathrm{m}^{7} \mathrm{GTP}$ (Table 2).

Reversal of poly(A)-mediated inhibition of translation by eIF-4A and PAB of HeLa mRNA. The effects of various initiation factors on poly(A)-mediated inhibition of translation were determined. The only initiation factor which showed some capacity to reverse poly(A)-mediated inhibition of translation was eIF-4A. During the course of these studies, we noted that reversal of the poly(A)-mediated inhibition of translation by eIF-4A was greater when the 

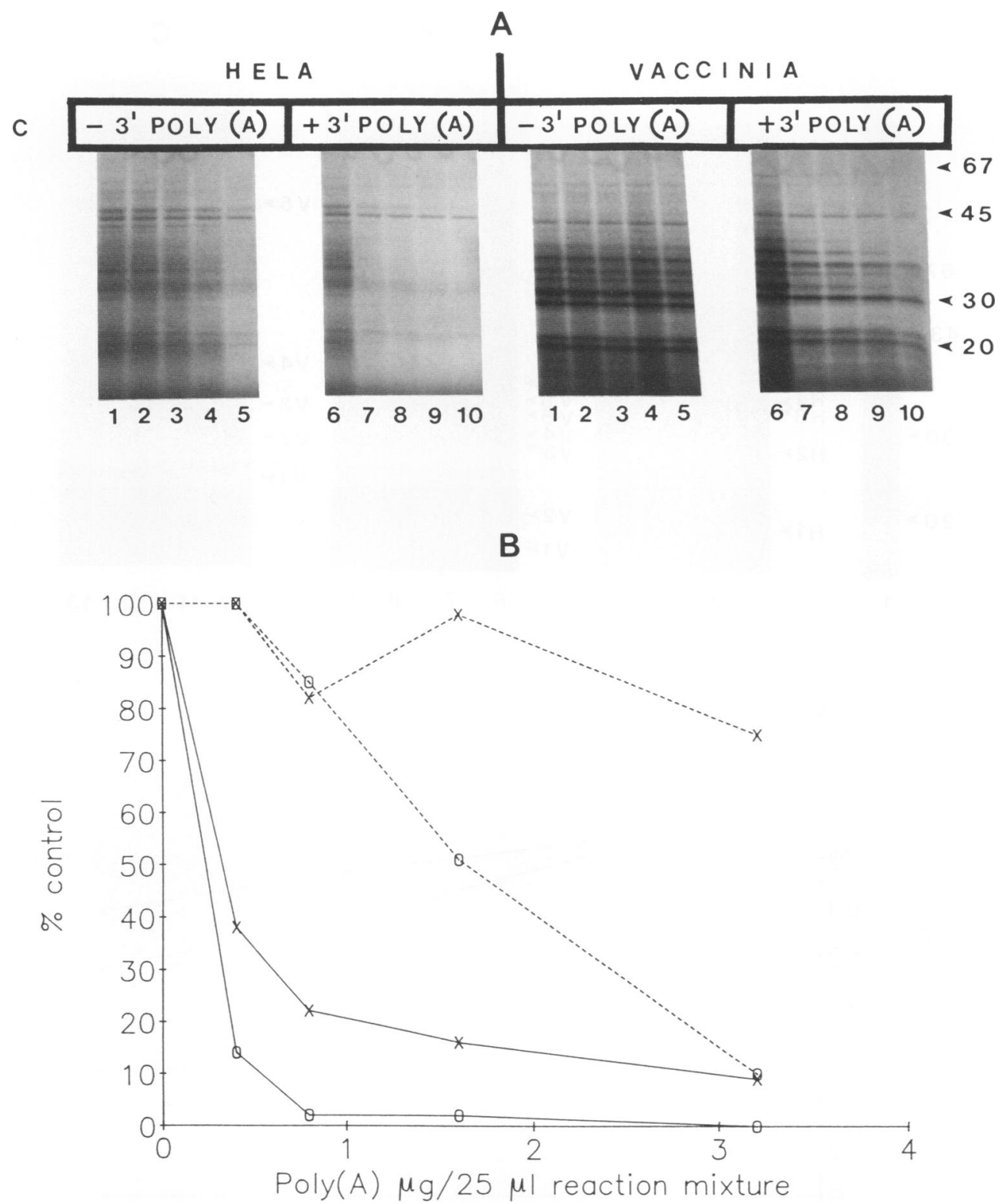

FIG. 3. (A) Effect of deadenylation of HeLa and VV mRNAs on the poly(A)-mediated inhibition of translation in the reticulocyte lysate system. HeLa cell and early VV mRNAs were deadenylated as described in Materials and Methods. Nuclease-treated reticulocyte lysates were programmed with deadenylated or mock-treated HeLa $(0.6 \mu \mathrm{g}$ per $25-\mu \mathrm{l}$ assay) or VV $(0.6 \mu \mathrm{g}$ per $25-\mu \mathrm{l}$ assay) mRNAs in the presence of various concentrations of poly $(\mathrm{A})_{150-300}$. Lanes 1 to 5 , deadenylated mRNAs; lanes 6 to 10, mock-treated mRNAs. Lanes were as follows: 1 and 6, no poly(A); 2 and 7, $0.4 \mu \mathrm{g}$ of poly(A); 3 and 8, $0.8 \mu \mathrm{g}$ of poly(A); 4 and 9, $1.6 \mu \mathrm{g}$ of poly(A); 5 and 10, 3.2 $\mu \mathrm{g}$ of poly(A). Twenty microliters of the reaction mixtures were subjected to 5 to $15 \%$ PAGE and exposed to an X-ray film. The numbers on the right of the autoradiograms represent molecular masses (kilodaltons) of marker proteins. (B) Relative translational efficiencies of deadenylated compared with adenylated HeLa and early VV mRNAs in the presence of various concentrations of poly(A). The percent translation of deadenylated HeLa and VV mRNAs was compared with that of the mRNAs with poly(A)s obtained by laser densitometry from the data in panel A. The translation of poly(A) ${ }^{-}$and poly(A) ${ }^{+}$mRNAs in the presence of various concentrations of poly(A) are plotted. $\mathrm{O}_{-}-\mathrm{O}, \mathrm{HeLa} \mathrm{mRNA}$ with poly(A); X-X, RNA with poly(A); $\bigcirc----O$ HeLa mRNA without poly(A); X----X, VV mRNA without poly(A).

reticulocyte lysates were programmed with mRNAs present in the total RNA extract of HeLa cells than when the lysates were programmed with mRNAs selected by oligo(dT) chromatography. For Table 3 , the reticulocyte lysates were programmed with HeLa cell mRNAs obtained either before or after oligo(dT) chromatography, and the extents of reversal of poly(A)-mediated inhibition of translation by various doses of eIF-4A were determined. It can be seen that the addition of poly $(A)_{150-300}$ reduced the translation of oligo(dT)-selected HeLa cell mRNAs by $17 \%$ of control and that 1,2 , and $4 \mu \mathrm{g}$ of eIF-4A increased translatability by 6 , 13 , and $18 \%$, respectively (Table 3 , comparison $B$ ). On the other hand, 1,2 , and $4 \mu \mathrm{g}$ of eIF-4A increased the translatability of the mRNAs which were not selected by oligo(dT) 
A

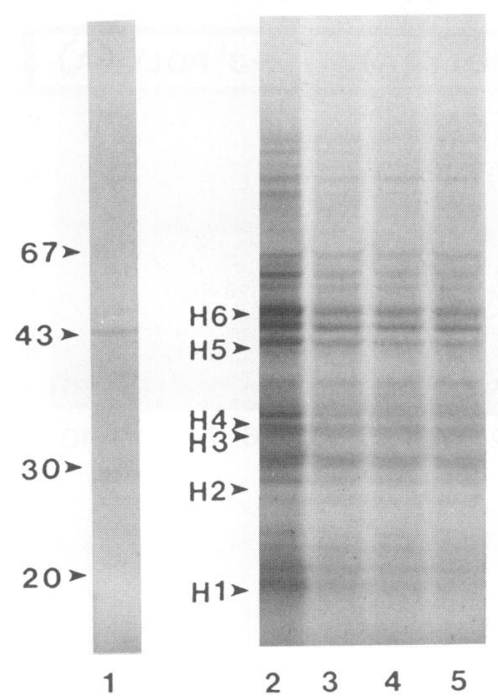

B

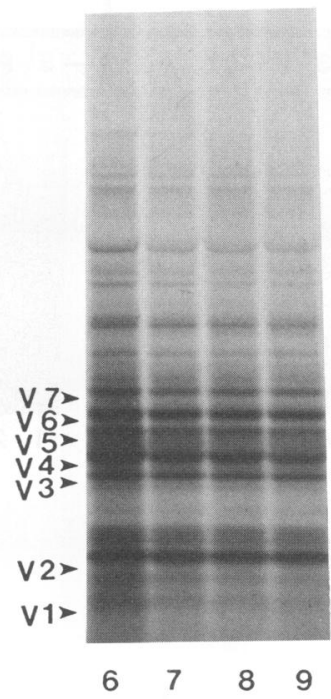

C

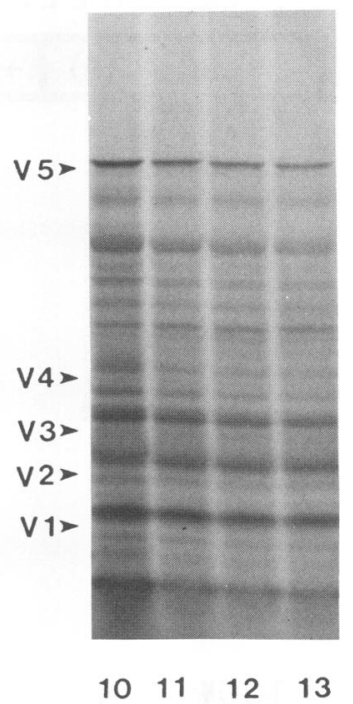

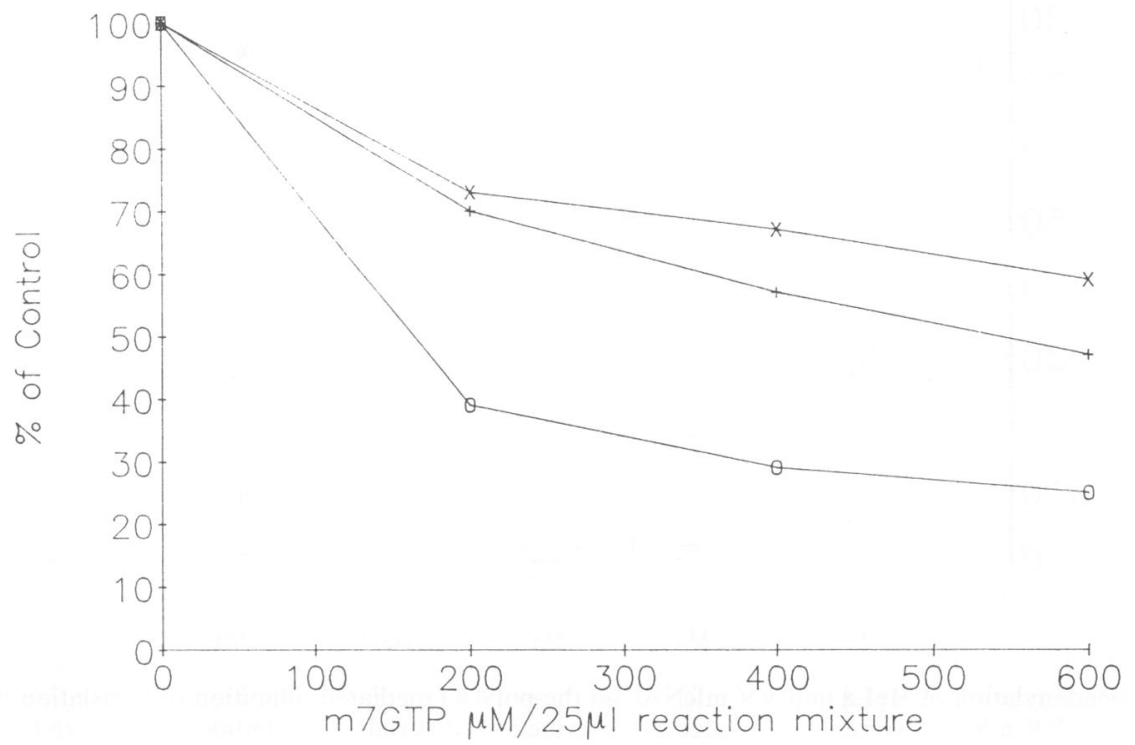

FIG. 4. (Top) Translational efficiencies of HeLa and VV mRNAs in the presence of various concentrations of $\mathrm{m}^{7} \mathrm{GTP}$. The translations of HeLa, early VV, and late VV mRNAs in the reticulocyte lysate system in the presence of 4,8 , and $12 \mu \mathrm{g}$ were determined. The extents of inhibition of various polypeptides were determined by laser densitometry and are given in Table 4 . The arrows specify the individual polypeptides, HeLa (H) or VV (V). Group A: lane 2, HeLa mRNA; lanes 3, 4, and 5, HeLa mRNA with 4, 8, and $12 \mu \mathrm{g}$ of $\mathrm{m}^{7} \mathrm{GTP}$, respectively. Group B: lane 6, early VV mRNA; lanes 7, 8, and 9, early VV mRNA with 4, 8, and $12 \mu \mathrm{g}$ of $\mathrm{m}^{7} \mathrm{GTP}$, respectively. Group C: lane 10 , late VV mRNA; lanes 11,12 , and 13 , late VV mRNA with 4,8 , and $12 \mu \mathrm{g} \mathrm{of}^{7} \mathrm{GTP}$, respectively. Lane 1 , no added RNA. The numbers on the left represent the molecular masses (kilodaltons) of marker proteins. (Bottom) Translation (percentage of that of control) of HeLa (O), early VV (X), and late VV (+) polypeptides in the presence of 4,8 , and $12 \mu \mathrm{g}$ of $\mathrm{m}^{7} \mathrm{GTP}$ was obtained by laser densitometry from the data in Table 1.

by 23,24 , and $37 \%$, respectively (Table 3 , comparison $\mathrm{A}$ ). These results demonstrate that eIF-4A can partially reverse the poly(A)-mediated inhibition of non-oligo(dT)-selected mRNAs more significantly than the inhibition of oligo(dT)selected mRNAs and that increasing the concentration of eIF-4A does not significantly alter the extent of reversal. The above results suggest that a component(s) which acts in concert with eIF-4A to significantly increase the reversal of poly(A)-mediated inhibition of translation is present in the total RNA extracts of HeLa cell RNAs. The composition of this putative factor is presently unknown. In a similar experiment with PAB $(2,6$, and $8 \mu \mathrm{g})$, it was observed that 
TABLE 1. Effect of $\mathrm{m}^{7} \mathrm{GTP}$ in the synthesis of HeLa and VV polypeptides determined by laser densitometry

\begin{tabular}{|c|c|c|c|c|c|c|c|c|c|c|c|c|c|c|c|c|}
\hline \multirow{2}{*}{$\mathrm{mRNA}^{a}$} & \multicolumn{16}{|c|}{ Synthesis of polypeptide no. ${ }^{b}$ : } \\
\hline & 1 & $\% \mathrm{C}$ & 2 & $\% \mathrm{C}$ & 3 & $\% \mathrm{C}$ & 4 & $\% \mathrm{C}$ & 5 & $\% \mathrm{C}$ & 6 & $\% \mathrm{C}$ & 7 & $\% \mathrm{C}$ & Mean & $\% \mathrm{C}$ \\
\hline HeLa & 1.81 & 100 & 1.01 & 100 & 1.86 & 100 & 1.56 & 100 & 1.45 & 100 & 2.74 & 100 & & & 1.74 & 100 \\
\hline$+200 \mu \mathrm{M} \mathrm{m}{ }^{7} \mathrm{GTP}$ & 0.68 & 38 & 0.41 & 41 & 0.90 & 48 & 0.44 & 28 & 0.53 & 37 & 1.03 & 38 & & & 0.67 & 39 \\
\hline$+400 \mu \mathrm{M} \mathrm{m} \mathrm{m}^{7} \mathrm{GTP}$ & 0.34 & 19 & 0.31 & 31 & 0.65 & 35 & 0.31 & 20 & 0.56 & 39 & 0.85 & 31 & & & 0.50 & 29 \\
\hline$+600 \mu \mathrm{M} \mathrm{m}{ }^{7} \mathrm{GTP}$ & 0.24 & 13 & 0.22 & 22 & 0.62 & 33 & 0.21 & 13 & 0.63 & 43 & 0.71 & 26 & & & 0.44 & 25 \\
\hline Early VV & 2.49 & 100 & 3.15 & 100 & 1.91 & 100 & 4.04 & 100 & 2.46 & 100 & 2.83 & 100 & 1.93 & 100 & 2.69 & 100 \\
\hline$+200 \mu \mathrm{M} \mathrm{m} \mathrm{m}^{7} \mathrm{GTP}$ & 1.44 & 58 & 2.66 & 84 & 1.48 & 77 & 3.08 & 76 & 1.62 & 66 & 2.23 & 79 & 1.20 & 62 & 1.96 & 73 \\
\hline$+400 \mu \mathrm{M} \mathrm{m}{ }^{7} \mathrm{GTP}$ & 1.18 & 47 & 2.43 & 77 & 1.45 & 76 & 2.61 & 65 & 1.70 & 69 & 2.01 & 71 & 1.18 & 61 & 1.79 & 67 \\
\hline$+600 \mu \mathrm{M} \mathrm{m} \mathrm{m}^{7} \mathrm{GTP}$ & 1.06 & 43 & 2.25 & 71 & 1.26 & 66 & 2.37 & 59 & 1.41 & 57 & 1.81 & 64 & 0.98 & 51 & 1.59 & 59 \\
\hline Late VV & 2.53 & 100 & 2.42 & 100 & 2.23 & 100 & 1.10 & 100 & 1.10 & 100 & & & & & 1.88 & 100 \\
\hline$+200 \mu \mathrm{M} \mathrm{m}^{7} \mathrm{GTP}$ & 2.11 & 83 & 1.61 & 67 & 1.51 & 68 & 0.66 & 60 & 0.69 & 63 & & & & & 1.32 & 70 \\
\hline$+400 \mu \mathrm{M} \mathrm{m}{ }^{7} \mathrm{GTP}$ & 1.75 & 69 & 1.31 & 54 & 1.25 & 56 & 0.51 & 46 & 0.56 & 51 & & & & & 1.08 & 57 \\
\hline$+600 \mu \mathrm{M} \mathrm{m}{ }^{7} \mathrm{GTP}$ & 1.41 & 56 & 1.27 & 52 & 1.01 & 45 & 0.38 & 35 & 0.36 & 33 & & & & & 0.89 & 47 \\
\hline
\end{tabular}

${ }^{a} \mathrm{HeLa}$, early VV, and late VV mRNAs were used at concentrations of $15,7.5$, and $7.5 \mu \mathrm{g}$ per $25-\mu \mathrm{l}$ assay, respectively.

${ }^{b} \mathrm{C}$, control.

$\mathrm{PAB}$ reverses the poly $(\mathrm{A})$-mediated inhibition of translation of oligo(dT)-selected (comparison B) and nonselected (comparison A) mRNAs (Table 4) to the same extent. These results suggest that free poly $(A)$ is inhibiting the initiation of protein synthesis by sequestering $\mathrm{PAB}$ from the solution.

In order to determine whether the mechanism of reversal of poly (A)-mediated inhibition of translation by eIF-4A is different from that of PAB, we determined the extent of reversal of poly(A)-mediated inhibition by eIF-4A in the presence of suboptimal levels of $P A B$. The results shown in Fig. 6, panel 1, lane 3, indicate that poly $(A)_{\text {un }}$ almost completely inhibited the translation of total cytoplasmic HeLa mRNAs. PAB $(1.5 \mu \mathrm{g})$ stimulated this inhibition to $20 \%$ of that of the untreated control (Fig. 6, panel 1, lane 4), but eIF-4A showed no stimulation (Fig. 6, panel 1, lane 5). Together, eIF-4A and PAB stimulated the poly(A)-mediated inhibition by $25 \%$ (Fig. 6, panel 1, lane 6). These results indicate that the limited activity of eIF-4A becomes demonstrable only if PAB is present.

A different result was obtained when poly $(A)_{150-300}$ was used in the presence of PAB and eIF-4A (Fig. 6, panel 2). This fraction of poly(A) also virtually inhibited the translation of HeLa cell mRNAs (Fig. 6, panel 2, lane 3), as did poly $(\mathrm{A})_{\mathrm{un}}$; however, in this case, eIF-4A $(1.3 \mu \mathrm{g})$ stimulated the poly(A)-mediated inhibition to $30 \%$ of that of the control (Fig. 6, panel 2, lane 5). PAB $(1.5 \mu \mathrm{g})$ stimulated this inhibition to about $40 \%$ of that of the control (Fig. 6, panel 2, lane 4), and together, PAB and eIF-4A stimulated the poly(A)-mediated inhibition to over $50 \%$ (Fig. 6, panel 2, lane 6). These results demonstrate that eIF-4A significantly reverses the poly $(A)_{150-300}$-mediated inhibition of translation of HeLa mRNAs and suggest that the stimulation of translation by $\mathrm{PAB}$ and $\mathrm{IF}-4 \mathrm{~A}$ is additive.

eIF-4A and PAB reverse the poly(A)-mediated inhibition of translation of early and late VV mRNAs, but the translation of late VV mRNAs is reversed only by PAB. We have previously shown that VV mRNAs are much more resistant to poly(A)mediated inhibition than several cellular mRNAs (3). We therefore tested the effect of eIF-4A and PAB on the poly (A)-mediated inhibition of both early and late viral mRNAs.

TABLE 2. Effect of $\mathrm{m}^{7} \mathrm{GTP}$ on the translation of separate or mixed HeLa and VV mRNAs: extent of polypeptide synthesis determined by laser densitometry

\begin{tabular}{|c|c|c|c|c|c|c|c|c|c|c|c|c|c|c|}
\hline \multirow{2}{*}{$\mathrm{mRNA}^{a}$} & \multicolumn{14}{|c|}{ Synthesis of polypeptide no. ${ }^{b}$ : } \\
\hline & 1 & $\% \mathrm{C}$ & 2 & $\% \mathrm{C}$ & 3 & $\% \mathrm{C}$ & 4 & $\% \mathrm{C}$ & 5 & $\% \mathrm{C}$ & 6 & $\% \mathrm{C}$ & Mean & $\% \mathrm{C}$ \\
\hline HeLa & 1.62 & 100 & 1.57 & 100 & 1.18 & 100 & 1.21 & 100 & 2.27 & 100 & & & 1.57 & 100 \\
\hline$+400 \mu \mathrm{M} \mathrm{m}^{7} \mathrm{GTP}$ & 0.65 & 40 & 0.16 & 10 & 0.50 & 42 & 0.30 & 25 & 0.66 & 29 & & & 0.45 & 29 \\
\hline$+600 \mu \mathrm{M} \mathrm{m}^{7} \mathrm{GTP}$ & 0.67 & 41 & 0.15 & 10 & 0.45 & 38 & 0.25 & 21 & 0.46 & 20 & & & 0.40 & 25 \\
\hline VV & 1.16 & 100 & 1.84 & 100 & 2.65 & 100 & 1.29 & 100 & 1.99 & 100 & 0.77 & 100 & 1.62 & 100 \\
\hline$+400 \mu \mathrm{M} \mathrm{m}^{7} \mathrm{GTP}$ & 0.52 & 45 & 1.02 & 55 & 2.37 & 89 & 0.90 & 70 & 1.05 & 53 & 0.37 & 48 & 1.04 & 64 \\
\hline$+600 \mu \mathrm{M} \mathrm{m}{ }^{7} \mathrm{GTP}$ & 0.53 & 46 & 0.95 & 52 & 2.24 & 85 & 0.80 & 62 & 0.89 & 45 & 0.33 & 43 & 0.96 & 59 \\
\hline HeLa with VV & & & & & & & & & & & & & & \\
\hline HeLa & 0.78 & 100 & 0.85 & 100 & 1.64 & 100 & & & & & & & 1.09 & 100 \\
\hline$+400 \mu \mathrm{M} \mathrm{m}{ }^{7} \mathrm{GTP}$ & 0.12 & 15 & 0.06 & 7 & 0.17 & 10 & & & & & & & 0.12 & 11 \\
\hline$+600 \mu \mathrm{M} \mathrm{m}{ }^{7} \mathrm{GTP}$ & 0.10 & 13 & 0.05 & 6 & 0.17 & 10 & & & & & & & 0.11 & 10 \\
\hline VV & 2.20 & 100 & 2.25 & 100 & 0.94 & 100 & 1.37 & 100 & 1.04 & 100 & & & 1.56 & 100 \\
\hline$+400 \mu \mathrm{M} \mathrm{m}{ }^{7} \mathrm{GTP}$ & 0.91 & 41 & 1.54 & 68 & 0.61 & 65 & 0.80 & 58 & 0.27 & 26 & & & 0.83 & 53 \\
\hline$+600 \mu \mathrm{M} \mathrm{m}^{7} \mathrm{GTP}$ & 0.90 & 41 & 1.42 & 63 & 0.53 & 56 & 0.73 & 53 & 0.20 & 19 & & & 0.76 & 49 \\
\hline
\end{tabular}

${ }^{a}$ For assays in which HeLa and VV mRNAs were used alone, concentrations of the mRNAs were 0.6 and $0.2 \mu \mathrm{g}$ per $25-\mu \mathrm{l}$ assay, respectively. For assays in which both types were used, concentrations of HeLa and VV mRNAs were 0.6 and $0.2 \mu \mathrm{g}$ per $25-\mu \mathrm{l}$ assay, respectively.

${ }^{b} \mathrm{C}$, control. 

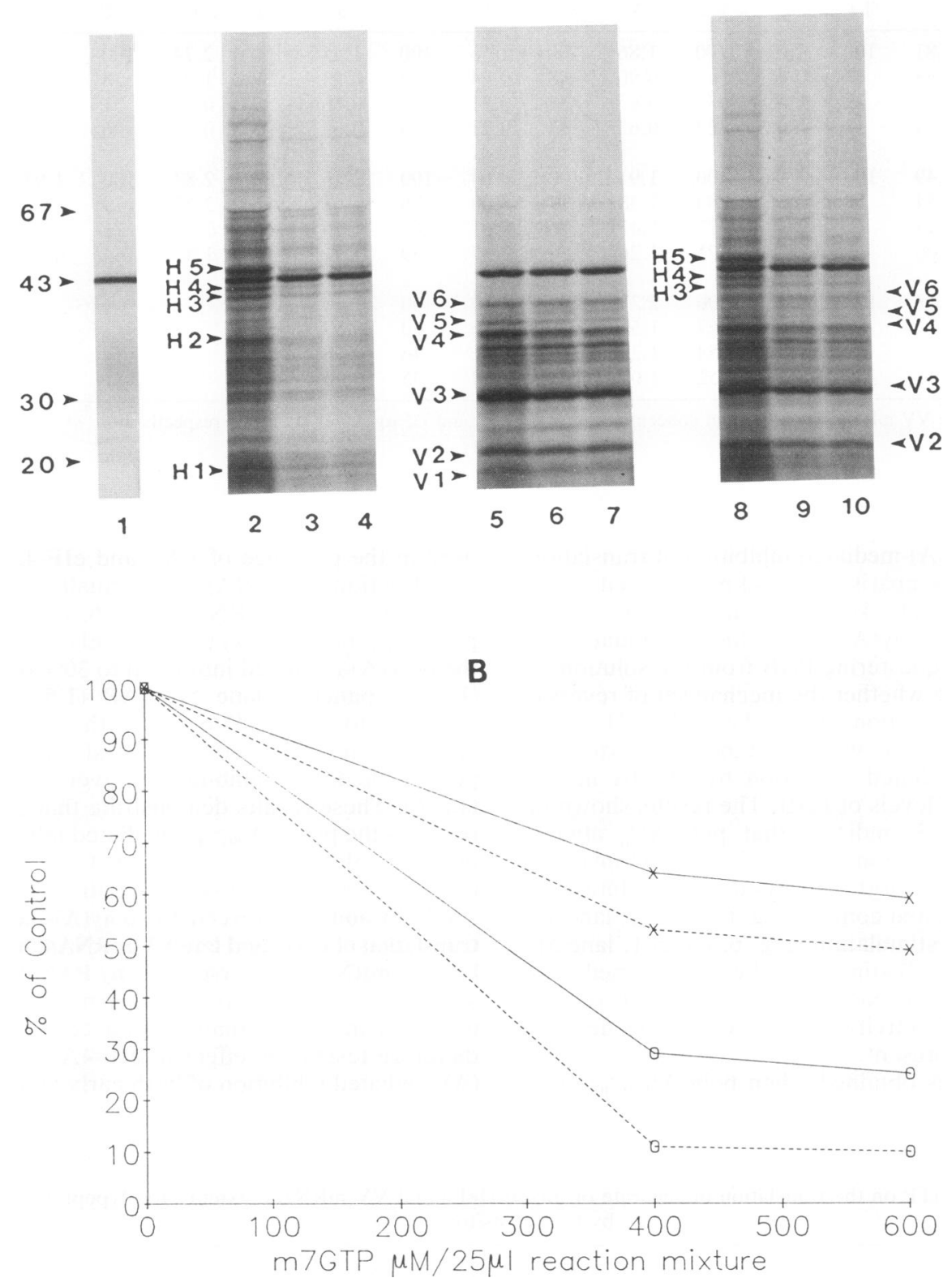

FIG. 5. Translational efficiencies of the mixed HeLa and VV mRNAs in the presence of various concentrations of $m^{7} G T P$. (A) HeLa and early VV mRNAs, either separately or mixed together, were translated in the reticulocyte lysate system in the presence of various concentrations of $m^{7}$ GTP. The arrowheads specify the individual polypeptides, HeLa (H) or VV (V). Lane 2, HeLa mRNA; lanes 3 and 4 , HeLa mRNA with 8 and $12 \mu \mathrm{g}$ of $\mathrm{m}^{7} \mathrm{GTP}$, respectively. Lane 5 , early VV mRNA; lanes 6 and 7 , early VV mRNA with 8 and $12 \mu \mathrm{g}$ of $\mathrm{m}^{7} \mathrm{GTP}$, respectively. Lane 8, HeLa plus early VV mRNA; lanes 9 and 10, HeLa plus early VV mRNA with 8 and $12 \mu \mathrm{g}$ of $\mathrm{m}^{7} \mathrm{GTP}$, respectively. Lane 1 , no added RNA. The numbers on the left represent the molecular masses (kilodaltons) of marker proteins. (B) Translation (percentage of that of control) of various polypeptides in the presence of 8 and $12 \mu \mathrm{g} \mathrm{of} \mathrm{m}^{7} \mathrm{GTP}$ from Table 2 is plotted. $\bigcirc-\bigcirc$, HeLa polypeptides; $\bigcirc---\bigcirc$, HeLa polypeptides from the mixture; X-X, VV polypeptides; X---X, VV polypeptides from the mixture.

It can be seen in Fig. 7 that the poly(A)-mediated inhibition of early VV mRNA translation is about $15 \%$ (lane 3 ) and that both PAB (lane 4) and eIF-4A (lane 5) reverse this slight inhibition. The poly(A)-mediated inhibition of late viral mRNA translation is about $38 \%$ (lane 9), and this inhibition is virtually reversed by PAB (lane 10) but not by eIF-4A (lane 11). The addition of both PAB and eIF-4A to the poly(A)-inhibited cell-free system reversed this inhibition (lane 12) to a degree similar to that of PAB alone (lane 10). These results show that the inhibition of early VV mRNA by poly(A) is reversed by both PAB and eIF-4A, but the inhibition of late VV mRNA translation is reversed only by 
TABLE 3. Reversal of poly(A)-mediated inhibition of translation by eIF-4A ${ }^{a}$

\begin{tabular}{|c|c|c|c|c|c|c|c|c|c|}
\hline \multirow{3}{*}{ mRNA } & \multirow{3}{*}{ Initiation factor } & \multicolumn{4}{|c|}{ Comparison A } & \multicolumn{4}{|c|}{ Comparison B } \\
\hline & & \multicolumn{2}{|c|}{ No poly(A) } & \multicolumn{2}{|c|}{$\operatorname{Poly}(A)_{150-300}$} & \multicolumn{2}{|c|}{ No poly(A) } & \multicolumn{2}{|c|}{$\operatorname{Poly}(A)_{150-300}$} \\
\hline & & $10^{3} \mathrm{cpm}$ & $\%$ of $\mathrm{C}$ & $10^{3} \mathrm{cpm}$ & $\%$ of $\mathrm{C}$ & $10^{3} \mathrm{cpm}$ & $\%$ of $\mathrm{C}$ & $10^{3} \mathrm{cpm}$ & $\%$ of $\mathrm{C}$ \\
\hline None & & 72 & & & & 69 & & & \\
\hline HeLa & & 237 & 100 & 78 & 33 & 259 & 100 & 50 & 17 \\
\hline HeLa & eIF-4A $(1 \mu \mathrm{g})$ & 211 & 100 & 119 & 56 & 234 & 100 & 54 & 23 \\
\hline HeLa & eIF-4A $(2 \mu \mathrm{g})$ & 219 & 100 & 125 & 57 & 248 & 100 & 75 & 30 \\
\hline HeLa & eIF-4A $(4 \mu \mathrm{g})$ & 211 & 100 & 126 & 60 & 195 & 100 & 68 & 35 \\
\hline
\end{tabular}

${ }^{a}$ For comparison A, mRNA found in total cytoplasmic RNA (15 $\mu$ g per $25-\mu$ l reaction mixture) was used. For comparison B, mRNA selected by oligo(dT)-cellulose chromatography $(0.2 \mu \mathrm{g}$ per $25-\mu \mathrm{l}$ reaction mixture) was used. $\mathrm{C}$, control.

PAB, suggesting that the $5^{\prime}$ poly(A) stretch found on most late VV mRNAs may, by some unknown manner, obstruct the action of eIF-4A. Neither eIF-4B nor eIF-4F, alone or in combination, had any effect on poly(A)-mediated inhibition of translation by VV mRNAs (data not shown).

\section{DISCUSSION}

The results of this study demonstrate that VV mRNAs are more efficient than HeLa cell mRNAs in initiating and translating in the presence of both poly(A) and $m^{7}$ GTP. A comparison between host and viral mRNAs indicates that the average length of poly $(\mathrm{A}) \mathrm{s}$ of host cell mRNAs is about 200 nucleotides (11), which is comparable to that of VV mRNAs $(37,48)$, and both mRNAs are known to be capped. Therefore, the question of what features provide VV mRNAs with a leading edge over HeLa mRNAs can be asked. We have recently demonstrated that in VV-infected cells, a population of nontranslating POLADS with poly $(\mathrm{A})$ chain lengths from 50 to over 200 nucleotides are produced. These POLADS function as free poly(A) and inhibit the translation of HeLa mRNAs and not that of VV mRNAs in the reticulocyte lysate system (51). In infected cells, shutoff or selective inhibition occurs in the presence of these POLADS; therefore, a priori VV mRNAs must be less sensitive to the effect of poly $(A)$ and thus require less PAB to initiate and translate. In this respect, VV mRNAs are behaving similarly to mRNAs without a poly(A) tail, which have been shown to be more resistant to the effect of free poly(A) $(14,21,33)$. It has been demonstrated that between 5 and $10 \%$ of the mRNAs synthesized both in vitro and in vivo by VV are devoid of poly(A) tails and that the polypeptides synthesized in a Krebs II ascites cell extract either by poly $(\mathrm{A})^{+}$or by poly $(\mathrm{A})^{-}$mRNAs are both quantitatively and qualitatively similar (37). Figure 2 shows that both total and oligo(dT)-cellulose-selected VV mRNAs are more resistant to exogenously added poly(A) than are HeLa mRNAs. However, in comparison, the VV mRNAs obtained from the total cytoplasmic RNA are much more resistant to the effect of exogenously added poly(A) than are the VV mRNAs selected by oligo(dT)-cellulose chromatography. This result suggests that in the total RNA pool from VV-infected cells, some of the mRNAs are without poly(A) tails, giving rise to a population of mRNAs which are more resistant to the inhibitory effect of exogenous poly(A). Results in Fig. 3, in which poly $(\mathrm{A})^{+} \mathrm{VV}$ mRNAs are more resistant than HeLa mRNAs to inhibition by poly(A), support this view. However, even more dramatic is the almost complete lack of poly(A) ${ }^{-}$VV mRNA inhibition of translation by poly(A). Thus, while the presence of a poly(A) tail clearly yields an mRNA that is sensitive to translation inhibition by poly(A), VV mRNA contains some unique feature, not present in HeLa mRNAs, that minimizes this inhibition. It is possible that this unique element is also responsible for the lack of sensitivity of VV mRNAs to inhibition by $\mathrm{m}^{7}$ GTP. A scanning model proposed by Kozak (26) has shown that the 43S ribosomal complex binds to the $5^{\prime}$ terminus of an mRNA and scans the $5^{\prime}$ noncoding region until it reaches the initiation codon. In recent years, a number of atypical picornavirus mRNAs which lack a cap structure and initiate translation internally upstream in the $5^{\prime}$ noncoding region without scanning have been found $(22,41-43)$. VV mRNAs are known to be capped, monocistronic structures, and one would expect that these mRNAs would be cap dependent. It was, therefore, unexpected to find that the cap analog, $\mathrm{m}^{7} \mathrm{GTP}$, was significantly less inhibitory for the translation of VV mRNAs compared with HeLa cell mRNAs (Fig. 4 and 5 and Tables 3 and 4). It is apparent that the cap structure is not absolutely required for the translation of VV early and late mRNAs, as it is for HeLa cell mRNAs. It is of interest to note that the 26S mRNA of Semliki Forest virus, which is known to be capped, is also not sensitive to a cap analog

TABLE 4. Reversal of poly(A)-mediated inhibition of translation by $\mathrm{PAB}^{a}$

\begin{tabular}{|c|c|c|c|c|c|c|c|c|c|}
\hline \multirow{3}{*}{ mRNA } & \multirow{3}{*}{$\begin{array}{l}\text { Initiation } \\
\text { factor }\end{array}$} & \multicolumn{4}{|c|}{ Comparison A } & \multicolumn{4}{|c|}{ Comparison B } \\
\hline & & \multicolumn{2}{|c|}{ No poly(A) } & \multicolumn{2}{|c|}{$\operatorname{Poly}(\mathrm{A})_{150-300}$} & \multicolumn{2}{|c|}{ No poly(A) } & \multicolumn{2}{|c|}{$\operatorname{Poly}(A)_{150-300}$} \\
\hline & & $10^{3} \mathrm{cpm}$ & $\%$ of $\mathrm{C}$ & $10^{3} \mathrm{cpm}$ & $\%$ of $\mathrm{C}$ & $10^{3} \mathrm{cpm}$ & $\%$ of $\mathrm{C}$ & $10^{3} \mathrm{cpm}$ & $\%$ of $\mathrm{C}$ \\
\hline None & & 46 & & & & 46 & & & \\
\hline HeLa & & 154 & 100 & 59 & 38 & 432 & 100 & 50 & 11 \\
\hline HeLa & РAB $(2 \mu \mathrm{g})$ & 205 & 100 & 90 & 44 & 690 & 100 & 112 & 16 \\
\hline HeLa & PAB $(6 \mu \mathrm{g})$ & 221 & 100 & 181 & 82 & 749 & 100 & 616 & 82 \\
\hline HeLa & РAB $(8 \mu \mathrm{g})$ & 204 & 100 & 204 & 100 & 661 & 100 & 644 & 98 \\
\hline
\end{tabular}

${ }^{a}$ For comparison A, mRNA found in total cytoplasmic RNA (15 $\mu \mathrm{g}$ per $25-\mu$ l reaction mixture) was used. For comparison B, mRNA selected by oligo(dT)-cellulose chromatography $(0.2 \mu \mathrm{g}$ per $25-\mu \mathrm{l}$ reaction mixture) was used. $\mathrm{C}$, control. 

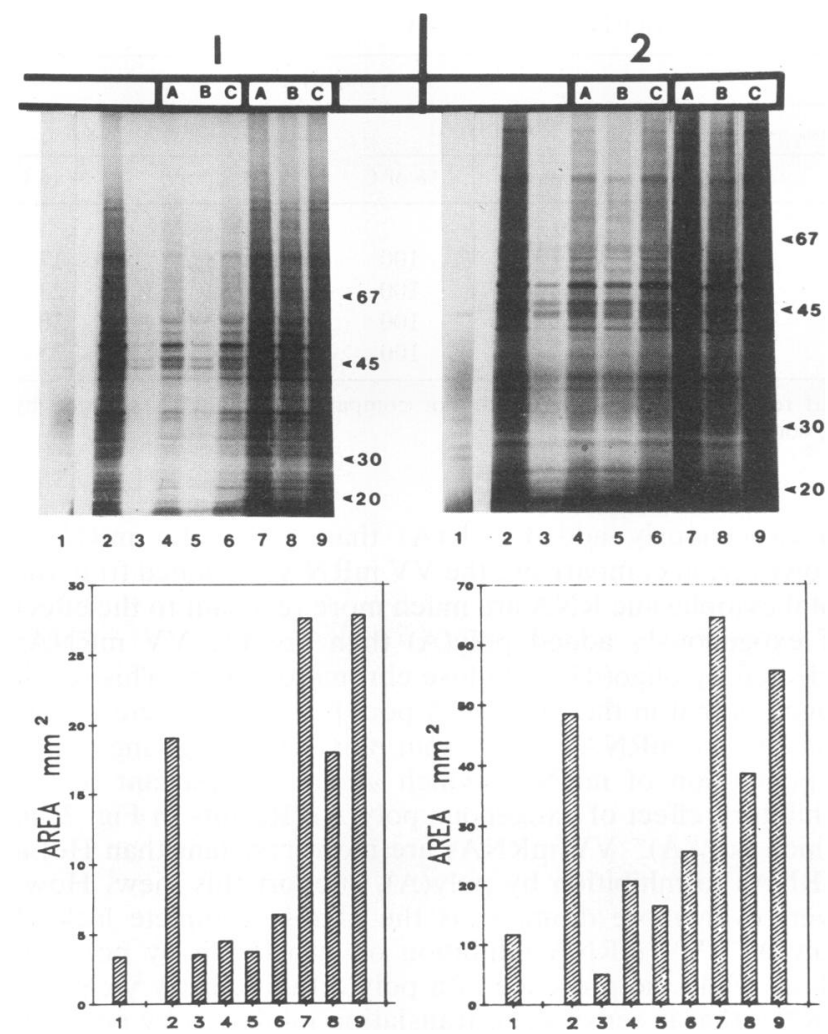

FIG. 6. Effects of eIF-4A and PAB on the inhibition of translation of HeLa mRNAs by poly(A) $)_{u n}$ and poly $(A)_{150-300}$. Nucleasetreated reticulocyte lysates $(25 \mu \mathrm{l})$ were programmed with $\mathrm{HeLa}$ mRNAs [10 $\mu \mathrm{g}$, non-oligo(dT) selected] (lanes 2 to 9) and in addition received either poly $(\mathrm{A})_{\mathrm{un}}(0.8 \mu \mathrm{g})($ panel 1$)$ or poly $(\mathrm{A})_{150-300}(0.8 \mu \mathrm{g})$ (panel 2) with eIF-4A $(1.3 \mu \mathrm{g})$, PAB $(1 \mu \mathrm{g})$, or eIF-4A and PAB combined. Lanes were as follows: 1, no added mRNA; 2, HeLa mRNA; 3, HeLa mRNA plus poly(A); 4, HeLa mRNA plus poly(A) plus PAB; 5 , HeLa plus mRNA plus poly(A) plus eIF-4A; 6, HeLa mRNA plus poly(A) plus eIF-4A plus PAB; 7, HeLa mRNA plus PAB; 8 , HeLa mRNA plus eIF-4A; 9, HeLa mRNA plus eIF-4A plus PAB. Twenty microliters of the reaction mixtures was subjected to 5 to $15 \%$ PAGE and exposed to an X-ray film. The numbers on the right of the autoradiograms represent molecular masses (kilodaltons) of marker proteins. The lower panel shows the magnitude of polypeptide synthesis determined by laser densitometry of the autoradiograms.

(52). Both Semliki Forest virus $26 \mathrm{~S}$ and VV mRNAs must possess additional features which make them capable of initiating under conditions of decreased cap-specific initiation factors. One of these features could be the 5 ' secondary structure with respect to the activity of eIF-4A in regulating translation. Considerable data which indicate that translational efficiency is inversely correlated with the secondary structure have been accumulated $(15,19,27-29,32,40)$. In this respect, it would be of great interest to construct reporter genes with early and late VV mRNA 5' leaders and determine their translational efficiencies in the presence of cap analogs.

It has been demonstrated that in vitro inhibition of translation by poly(A) can be essentially overcome by the exogenous addition of PAB, indicating that this inhibition may be due to the depletion of endogenous PAB (14). These observations in the in vitro system have been confirmed by in vivo data which demonstrate that $\mathrm{PAB}$ is essential for
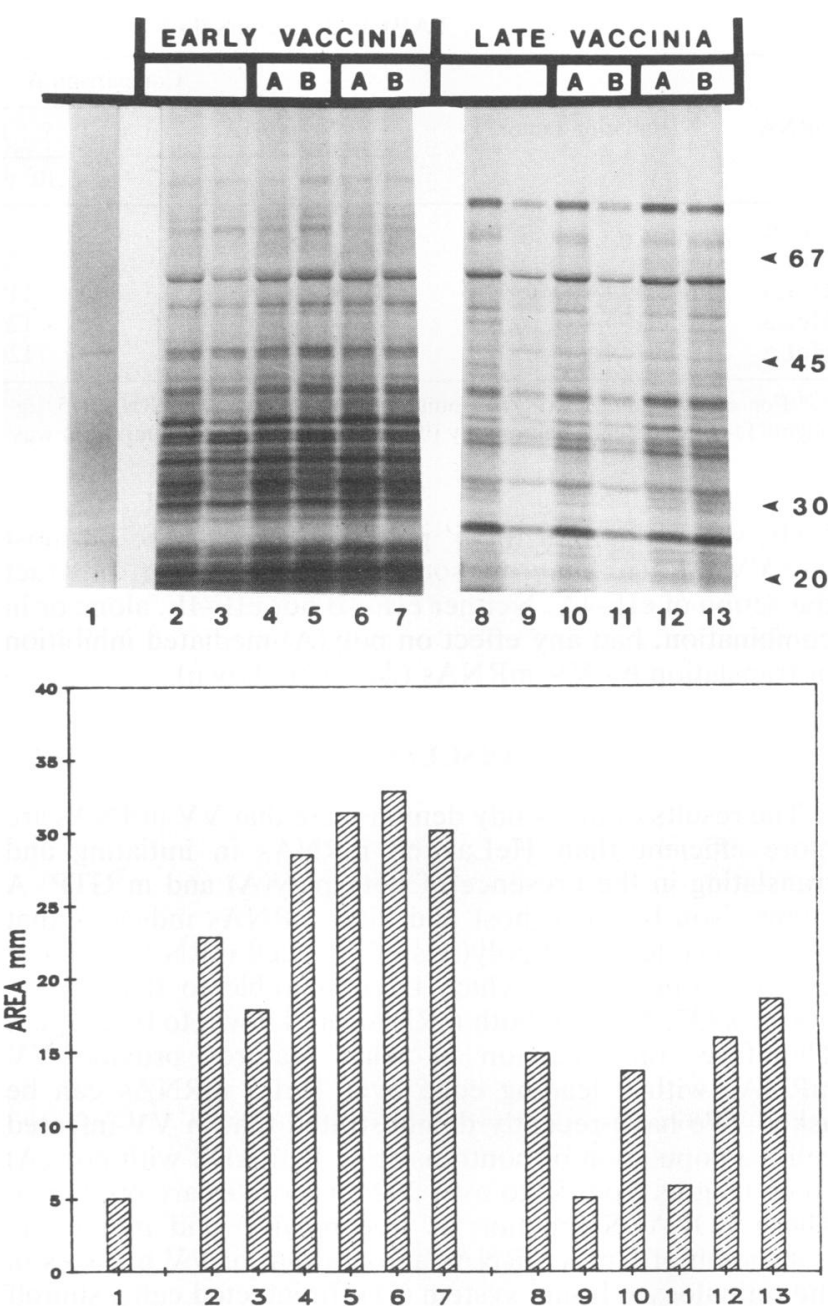

FIG. 7. The effects of eIF-4A and PAB on the poly $(A)_{u n}$-mediated inhibition of translation of early and late VV mRNA. Nucleasetreated reticulocyte lysates $(25 \mu \mathrm{l})$ were programmed with either early $(5 \mu \mathrm{g})$ (lanes 2 to 7$)$ or late $(5 \mu \mathrm{g})$ (lanes 8 to 13) VV mRNAs [non-oligo(dT) selected] and in addition received either poly(A) (1 $\mu \mathrm{g})$ (lanes 3 and 9) or poly(A) with PAB $(4 \mu \mathrm{g})$ (lanes 4 and 10), poly(A) with eIF-4A (1.3 $\mu$ g) (lanes 5 and 11), PAB (lanes 6 and 12), or eIF-4A (lanes 7 and 13). Lane 1, no added RNA. Twenty microliters of the reaction mixtures was subjected to 5 to $15 \%$ PAGE and exposed to an X-ray film. The numbers on the right of the autoradiograms represent molecular masses (kilodaltons) of marker proteins. The lower panel shows the magnitude of polypeptide synthesis determined by laser densitometry of the autoradiograms.

translation, because depletion of PAB results in the inhibition of both initiation and poly(A) tail shortening (44). Exogenously added poly(A) probably acts as a sink to soak up free PAB, thus depriving the poly(A) tails of mRNAs of the ability to interact with PAB. It has been demonstrated that $\mathrm{PAB}$ binds to poly(A) with a periodicity covering a length of 27 (A)s (9). Thus, an increase in the size of free poly $(A)$ should theoretically cause a depletion of PAB molecules, which would in turn decrease their availability to bona fide mRNAs, which require $\mathrm{PAB}$ for initiation of translation. Our results in Fig. 1 demonstrate that both $\operatorname{poly}(A)_{u n}$ and poly $(A)_{150-300}$ completely inhibit the translation of HeLa cell mRNAs. The poly(A)-mediated inhibition 
of both early and late VV mRNAs, however, is significantly less with poly(A) un (Fig. 1 and 7) and negligible with $\operatorname{poly}(A)_{150-300}$ (data not shown). These results support the view that both early and late viral mRNAs have the capacity to initiate translation with limiting amounts of PAB. It is of interest that most late poxvirus mRNAs possess $5^{\prime}$ poly(A) sequences $(1,10,38,47,54)$, and recently it was demonstrated that even some early VV mRNAs are polyadenylated at their $5^{\prime}$ ends (20). The role of the $5^{\prime}$ poly(A) stretches in translation or selectivity still remains undetermined.

In order to test the effects of single initiation factors on the poly(A)-mediated inhibition of translation, we used purified initiation factors. Only purified eIF-4A was capable of reversing some of the inhibition of HeLa cell mRNA translation caused by poly $(A)_{150-300}$, but not the inhibition caused by the longer chains of poly(A) (Fig. 6). The poly(A)mediated inhibition of early VV mRNAs caused by $\operatorname{poly}(A)_{u n}$ was completely reversed by eIF-4A; however, eIF-4A showed no effect on the poly(A)-mediated inhibition of the late mRNAs (Fig. 7). The reason for this result is presently not understood. Early in infection, VV mRNAs, which are more resistant to the effect of poly $(A)_{150-300}$ than host mRNAs, might escape its inhibitory effects by having reduced requirement for unwinding of the mRNA to allow ribosome binding. While this may be part of the poly(A) inhibition scheme, the major portion of the reversal of poly(A)-mediated inhibition of translation is probably mediated by $P A B$. The reversal by eIF-4A is in addition to the reversal brought about by $\mathrm{PAB}$, and eIF-4A reversal becomes more evident when the amount of PAB is above limiting quantities (Fig. 6 and 7). Other initiation factors tested, such as eIF-4B and eIF-4F, had no effect on reversal of inhibition (data not shown). Previous results (51) and the results in this study suggest that 150 - to 300 -nucleotide poly(A), or poly(A) of a similar size, plays a major biological role in the selective inhibition brought about by $\mathrm{VV}$ infection. It remains to be shown that when such poly(A) molecules are introduced into intact cells either by microinjection or by transfection, they will cause inhibition of host cell translation.

\section{ACKNOWLEDGMENTS}

We thank Santo Scribani for expert technical assistance.

This research was supported by Public Health Service grant R01 A1 2436-03.

\section{REFERENCES}

1. Ahn, B. Y., and B. Moss. 1989. Capped poly(A) leaders of variable lengths at the $5^{\prime}$ ends of vaccinia virus late mRNAs. J. Virol. 63:226-232.

2. Bablanian, R. 1975. Structural and functional alterations in cultured cells infected with cytocidal viruses. Prog. Med. Virol. 19:40-83.

3. Bablanian, R., and A. K. Banerjee. 1986. Poly(riboadenylic acid) preferentially inhibits in vitro translation of cellular mRNA compared with vaccinia virus mRNA: possible role in vaccinia virus cytopathology. Proc. Natl. Acad. Sci. USA 83:1290-1294.

4. Bablanian, R., G. Coppola, P. Masters, and A. K. Banerjee. 1986. Characterization of vaccinia virus transcripts involved in selective inhibition of host protein synthesis. Virology 148:375380.

5. Bablanian, R., G. Coppola, S. Scribani, and M. Esteban. 1981. Inhibition of protein synthesis by vaccinia virus. III. The effect of UV-irradiated virus on inhibition of protein synthesis. Virology 112:1-12.

6. Bablanian, R., G. Coppola, S. Scribani, and M. Esteban. 1981. Inhibition of protein synthesis by vaccinia virus. IV. The role of low molecular weight virus RNA in the inhibition of protein synthesis. Virology 112:13-24.

7. Bablanian, R., M. Esteban, B. Baxt, and J. A. Sonnabend. 1978. Studies on the mechanism of vaccinia virus cytopathic effects. Inhibition of protein synthesis in infected cells is associated with virus-induced RNA synthesis. J. Gen. Virol. 39:391-402.

8. Bablanian, R., S. K. Goswami, M. Esteban, and A. K. Banerjee. 1987. Selective inhibition of protein synthesis by synthetic and vaccinia virus-core synthesized poly(riboadenylic acids). Virology 161:366-373.

9. Baer, B. W., and R. D. Kornberg. 1980. Repeating structure of cytoplasmic poly(A)-ribonucleoprotein. Proc. Natl. Acad. Sci. USA 77:1890-1982.

10. Bertholet, C., E. Van Meir, B. ten Heggeler-Bordier, and R. Wittek. 1987. Vaccinia virus produces late mRNAs by discontinuous synthesis. Cell 50:153-162.

11. Brawerman, G. 1981. The role of poly(A) sequence in mammalian mRNA. Crit. Rev. Biochem. 10:1-38.

12. Brown, M., J. W. Dorson, and F. J. Bollum. 1973. Terminal riboadenylate transferase: a poly(A) polymerase in purified vaccinia virus. Virology 12:203-208.

13. Coppola, G., and R. Bablanian. 1983. Discriminatory inhibition of protein synthesis in cell-free systems by vaccinia virus transcripts. Proc. Natl. Acad. Sci. USA 80:75-79.

14. de Sa, M.-F. G., N. Strandart, C. M. de Sa, O. Akhayat, M. Huesca, and K. Scherrer. 1988. The poly(A)-binding protein facilitates in vitro translation of poly(A)-rich mRNA. Eur. J. Biochem. 176:521-526.

15. Edery, I., J. Pelletier, and N. Sonenberg. 1987. Role of eukaryotic mRNA cap binding protein in regulation of translation, $p$. 335-361. In J. Ilan (ed.), Translational regulation of gene expression. Plenum Publishing Corp., New York.

16. Fairbanks, G., Jr., C. Levinthal, and R. H. Reeder. 1965 Analysis of ${ }^{14} \mathrm{C}$-labeled proteins by disc electrophoresis. Biochem. Biophys. Res. Commun. 20:393-399.

17. Grifo, J. A., S. M. Tahara, J. P. Leis, M. A. Morgan, A. J. Shatkin, and W. C. Merrick. 1982. Characterization of eukaryotic initiation factor 4A, a protein involved in ATP-dependent binding of globin mRNA. J. Biol. Chem. 257:5246-5252.

18. Grifo, J. A., S. M. Tahara, M. A. Morgan, A. J. Shatkin, and W. C. Merrick. 1983. New initiation factor activity required for globin mRNA translation. J. Biol. Chem. 258:5804-5810.

19. Guan, K. L., and H. Weiner. 1989. Influence of the $5^{\prime}$ end region of aldehyde dehydrogenase mRNA on translational efficiency. J. Biol. Chem. 264:17764-17769.

20. Ink, B. S., and D. J. Pickup. 1990 . Vaccinia virus directs the synthesis of early mRNAs containing $5^{\prime}$ poly(A) sequences. Proc. Natl. Acad. Sci. USA 87:1536-1540.

21. Jacobson, A., and M. Favreau. 1983. Possible involvement of poly(A) in protein synthesis. Nucleic Acids Res. 11:6353-6368.

22. Jang, S. H., H.-G. Kraüsslich, M. J. H. Nicklin, G. M. Duke, A. C. Palmenberg, and E. Wimmer. 1988. A segment of the 5' nontranslated region of encephalomyocarditis virus RNA directs internal entry of ribosomes during in vitro translation. $J$. Virol. 62:2636-2643.

23. Joklik, W. I. 1962. Purification of four strains of poxvirus. Virology 18:9-18.

24. Kates, J. 1970. Transcription of the vaccinia virus genome and the occurrence of polyriboadenylic acid sequences in messenger RNA. Cold Spring Harbor Symp. Quant. Biol. 35:743-752.

25. Kates, J., and J. Beeson. 1970. RNA synthesis in vaccinia virus. I. The mechanism of synthesis and release of RNA in vaccinia cores. J. Mol. Biol. 50:1-18.

26. Kozak, M. 1978. How do eukaryotic ribosomes select initiation regions in messenger RNA? Cell 15:1109-1123.

27. Kozak, M. 1980. Influence of mRNA secondary structure on binding and migration of 40S ribosomal subunits. Cell 19:79-80.

28. Kozak, M. 1988. Leader length and secondary structure modulate mRNA function under conditions of stress. Mol. Cell. Biol. 8:2737-2744.

29. Kozak, M. 1989. Circumstances and mechanisms of inhibition of translation by secondary structure in eukaryotic mRNAs. Mol Cell. Biol. 9:5134-5142.

30. Krystosek, A., M. L. Cawthon, and D. Kabat. 1975. Improved 
methods for purification and assay of eukaryotic messenger ribonucleic acids and ribosomes. J. Biol. Chem. 250:6077-6084.

31. Laemmli, U. K. 1970. Cleavage of structural proteins during the assembly of the head of bacteriophage T4. Nature (London) 227:680-685.

32. Lawson, T. G., B. K. Ray, J. T. Dodds, J. A. Grifo, R. D. Abramson, W. C. Merrick, D. F. Betsch, H. L. Weith, and R. E. Thach. 1986. Influence of 5 ' proximal secondary structure on the translational efficiency of eukaryotic mRNAs and on their interaction with initiation factors. J. Biol. Chem. 261:13979 13989.

33. Lemay, G., and S. Millward. 1986. Inhibition of translation in L-cell lysates by free polyadenylic acid: differences in sensitivity among different mRNAs and possible involvement of an initiation factor. Arch. Biochem. Biophys. 249:191-198.

34. Lodish, H. F., and D. G. Nathan. 1972. Regulation of hemoglobin synthesis. J. Biol. Chem. 247:7822-7829.

35. Moss, B., and E. N. Rosenblum. 1974. Vaccinia virus polyriboadenylate polymerase. Covalent linkage of the product with polyribonucleotide and polydeoxyribonucleotide primers. J. Virol. 14:86-98.

36. Munroe, D., and A. Jacobson. 1990. mRNA poly(A) tail, a 3' enhancer of translational initiation. Mol. Cell. Biol. 10:34413455 .

37. Nevins, J. A., and Joklik, W. K. 1975. Poly(A) sequences of vaccinia virus messenger RNA: nature, mode of addition and function during translation in vitro and in vivo. Virology 63:114.

38. Patel, D. D., and D. J. Pickup. 1987. Messenger RNAs of a strongly-expressed late gene of cowpox virus contain 5'-terminal poly(A) sequences. EMBO J. 6:3787-3794.

39. Pelham, H. R. B., and R. J. Jackson. 1976. An efficient mRNAdependent translation system from reticulocyte lysates. Eur. J. Biochem. 67:247-256.

40. Pelletier, J., and N. Sonenberg. 1985. Insertion mutagenesis to increase secondary structure within the $5^{\prime}$ non-coding region of a eukaryotic mRNA reduces translational efficiency. Cell 40: 515-526.

41. Pelletier, J., and N. Sonenberg. 1988. Internal initiation of translation of eukaryotic mRNA directed by a sequence derived from poliovirus RNA. Nature (London) 334:320-325.

42. Pelletier, J., and N. Sonenberg. 1989. Internal binding of eucaryotic ribosomes on poliovirus RNA: translation in HeLa cell extracts. J. Virol. 63:441-444.

43. Rueckert, R. 1990. Picornaviridae and their replication, $p$ 507-548. In B. N. Fields, D. M. Knipe, R. M. Chanock, M. S Hirsh, J. L. Melnick, T. P. Monath, and B. Roizman (ed.), Virology, vol. 1, 2nd ed. Raven Press, Ltd., New York.

44. Sachs, A. B., and R. W. Davis, 1989. The poly(A) binding protein is required for poly $(\mathrm{A})$ shortening and $60 \mathrm{~S}$ ribosomal subunit-dependent translation initiation. Cell 58:857-867.

45. Schreier, M. H., and T. Staehelin. 1973. Initiation of mammalian protein synthesis: the importance of ribosome and initiation factor quality for the efficiency of in vitro systems. J. Mol. Biol. 73:329-349.

46. Schrom, M., and R. Bablanian. 1979. Inhibition of protein synthesis by vaccinia virus. I. Characterization of an inhibited cell-free protein-synthesizing system from infected cells. Virology 99:319-328.

47. Schwer, B., P. Visca, J. C. Vos, and H. G. Stunnenberg. 1987. Discontinuous transcription or RNA processing of vaccinia virus late messengers results in a $5^{\prime}$ poly(A) leader. Cell 50:163-169.

48. Sheldon, R., C. Jurale, and J. Kates. 1972. Detection of polyadenylic acid sequences in viral and eukaryotic RNA. Proc. Natl. Acad. Sci. USA 69:417-421.

49. Sheldon, R., and J. Kates. 1974. Mechanism of poly(A) synthesis by vaccinia virus. J. Virol. 14:214-224.

50. Stoltzfus, C. M., A. J. Shatkin, and A. K. Banerjee. 1973 Absence of polyadenylic acid from reovirus messenger ribonucleic acid. J. Biol. Chem. 218:7993-7998.

51. Su, M. J., and R. Bablanian. 1990. Polyadenylated RNA sequences from vaccinia virus-infected cells selectively inhibit translation in a cell-free system: structural properties and mechanism of inhibition. Virology 179:679-693.

52. van Steeg, H., A. Thomas, S. Verbeek, M. Kasperaitis, H. O. Voorma, and R. Benne. 1981. Shutoff of neuroblastoma cell protein synthesis by Semliki Forest virus: loss of ability of crude initiation factors to recognize early Semliki Forest virus and host mRNA's. J. Virol. 38:728-736.

53. Voorma, H. O., H. Goumans, N. Amesz, and R. Benne. 1983. The control of the rate of initiation of eukaryotic protein synthesis. Curr. Top. Cell Regul. 22:51-70.

54. Wright, C. F., and B. Moss. 1987. In vitro synthesis of vaccinia virus late mRNA containing a $5^{\prime}$ poly(A) leader sequence. Proc. Natl. Acad. Sci. USA 84:8883-8887. 